\title{
Excision of a traumatic fibroma with diode laser in a pediatric patient: case report ${ }^{1}$
}

\author{
Escisión de un fibroma traumático con láser de diodo en paciente \\ pediátrico: reporte de caso $^{1}$
}

Isabel Cristina Silva Mancera ${ }^{2}$, Francia Elena Triana Escobar ${ }^{3}$, Libia Soto Llanos ${ }^{4}$

\begin{abstract}
This is a clinical case with no financing of any kind, just the mother's informed consent to report the case.
DDS and Periodontist, Universidad del Valle, Master in dental laser therapy, University of Aachen, Germany. isilvam@yahoo.es

DDS, Universidad del Valle, Pediatric Dentistry and Maxillary Orthopedics, Universidad del Valle, assistant professor, School of Dentistry, Universidad del Valle. franciaelenatriana@hotmail.com

4 DDS, Universidad del Valle, Pediatric Dentist, Universidad CES, Medell n, Master in Administration, Universidad del Valle, Professor, School of Dentistry, Universidad del Valle. libisotto@hotmail.com
\end{abstract}

\begin{tabular}{|c|c|}
\hline \multirow[b]{2}{*}{$\begin{array}{l}\text { Keywords: } \\
\text { diode laser, } \\
\text { fibroma, reactive } \\
\text { hyperplasia, } \\
\text { chromophores }\end{array}$} & ABSTRACT \\
\hline & $\begin{array}{l}\text { Fibroma is currently considered the most common reactive hyperplasia of fibrous connective tissue in } \\
\text { response to local trauma in the oral cavity. This case deals with the excision of a traumatic fibroma using } \\
\text { diode laser (Epic X, wavelength of 940nm, continuous mode, } 5 \mathrm{~W} \text { power), whose energy is absorbed by } \\
\text { hemoglobin and melanin (chromophores) and is indicated in soft tissue surgeries, favoring coagulation. The } \\
\text { results are consistent with the benefits demonstrated in the scientific literature: better visibility in the surgical } \\
\text { act due to achieved hemostasis, excellent postoperative phase due to the absence of pain and inflammation, } \\
\text { with no need for analgesic medication, no use of sutures, no scarring and no recurrence. It is a safe and fast } \\
\text { procedure that also allows performing a histopathological study without altering the tissues to be examined. } \\
\text { In the case presented here, the histopathological study confirmed the presumptive diagnosis of fibroma. }\end{array}$ \\
\hline & RESUMEN \\
\hline $\begin{array}{l}\text { Palabras } \\
\text { clave: I ser de } \\
\text { diodo, fibroma, } \\
\text { hiperplasia } \\
\text { reactiva, } \\
\text { crom foros }\end{array}$ & $\begin{array}{l}\text { El fibroma es considerado actualmente como la } \mathrm{m} \text { s com } \mathrm{n} \text { hiperplasia reactiva de tejido conectivo fibroso } \\
\text { en respuesta a un trauma local en la cavidad bucal. En este caso se menciona la escisi n de un fibroma } \\
\text { traum tico utilizando laser de diodo (Epic X, longitud de onda de 940nm, modo continuo, potencia } 5 \mathrm{~W} \text { ), } \\
\text { cuya energ a es absorbida por la hemoglobina y la melanina (crom foros), indicado en cirug as de tejidos } \\
\text { blandos, favoreciendo la coagulaci n. Los resultados est } \mathrm{n} \text { acordes con los beneficios demostrados en } \\
\text { la literatura cient fica: mejor visibilidad en el acto quir rgico por la hemostasia lograda, postoperatorio } \\
\text { excelente por la ausencia de dolor e inflamaci n, sin necesidad de medicaci n analg sica ni uso de suturas, } \\
\text { no produce aparici n de cicatriz y no recidiva; ofrece seguridad y rapidez en el procedimiento. Permite la } \\
\text { realizaci n de estudio histopatol gico sin alterar los tejidos a examinar. En el caso presentado, el estudio } \\
\text { histopatol gico comprob el diagn stico presuntivo de fibroma. }\end{array}$ \\
\hline
\end{tabular}

Submitted: April 24/2018 - Accepted: October 23/2018

How to quote this article: Silva-Mancera IC,Triana-Escobar FE, Soto-Llanos L. Excision of a traumatic fibroma with diode laser in a pediatric patient: case report. Rev Fac Odontol Univ Antioq. 2019; 31(1-2): 162-170. DOI: http://dx.doi.org/10.17533/udea.rfo.v31n1-2a14 


\section{INTRODUCTION}

Traumatic fibroma (TF) is a reactive hyperplasia of dense connective tissue in response to local trauma. ${ }^{1}$ It can occur in any organ of the body and is also known as irritation fibroma, focal fibrous hyperplasia, fibrous nodule or fibroepithelial polyp. ${ }^{2}$ TF presents as an exophytic lesion, sessile or pedunculated, round or ovoid, asymptomatic, with a smooth surface and firm or soft consistency depending on the degree of fibrosis. Its diameter can vary from $1 \mathrm{~mm}$ to $2 \mathrm{~cm}$. The surface color is usually similar to the surrounding mucosa, but it may be hyperkeratotic or ulcerated in response to chronic trauma. It is of a long evolution and can appear in any place of the oral cavity; however, it appears most frequently in the tongue, palate and cheeks-the sites with the highest probability of suffering this type of trauma. ${ }^{3}$ It also frequently appears in the oral mucosa along the plane of occlusion of maxillary and mandibular teeth. ${ }^{4}$

The most common traumatic agents include occlusal trauma, lip biting and irritation caused by poor tooth position, irregular dental edges, fractured restorations, dental calculus, prosthetic apparatuses, orthodontics, and maladapted orthopedics. ${ }^{5}$

Fibromas are seen more frequently in adults, but they can occur in individuals of any age and sex. ${ }^{6}$ However, some authors claim that they are more predominant in females. ${ }^{5-7}$

Histologically, TF consists of a tissue of extremely dense hyperplastic collagen fibers, arranged in an irradiated, circular or random manner, with a variable degree of vascularization. If the lesion is not ulcerated, it is covered by keratinized squamous epithelium; if it is ulcerated, it can infiltrate with inflammatory cells. Recurrence is possible if the cause is not eliminated. ${ }^{6}$

Among the possible differential diagnoses of TF are other types of inflammatory fibrous hyperplasia, depending on location, such as pyogenic granuloma, inflammatory papillary hyperplasia, peripheral giant-cell granuloma, gingival fibromatosis and drug-induced gingival hyperplasia, although the latter have more generalized presentations in the oral cavity. ${ }^{5}$

For other authors, as a lesion that can occur anywhere in the oral mucosa, TF also has a wide range of differential diagnoses, ranging from traumatic lesions (fibrosed mucoceles), neurogenic lesions (neurofibromatosis), lipomas, epithelial tumors (squamous papilloma), inflammatory/reactive hyperplasia of soft tissues, ${ }^{7}$ and even schwannomas. ${ }^{6}$

Treatment for all common reactive lesions includes total surgical excision with conventional scalpel, laser or electrosurgery. Treatment should also include the elimination of etiology, such as replacement of defective restorations and elimination of traumatic habits. ${ }^{8}$

As noted above, surgical removal can be performed with conventional scalpel, electrosurgery, infrared lasers (diodes, erbium, neodymium and $\mathrm{CO}_{2}$ ), or through cryosurgery. In comparing these alternatives, laser provide patients with the best postoperative phase and some advantages as described by Bornstein et $\mathrm{al}^{9}$ and Rossmann et al: ${ }^{10}$

1. Excellent visibility of the surgical area due to the rapid ablation of soft tissue, including lymphatic and blood vessels, causing adequate sealing, which favors a more precise elimination of the pathology.

2. Minimum contact with pathological tissues. 
3. The laser sterilizes, reducing the risk of infections.

4. It dramatically reduces pain, inflammation and postoperative infections, while also sealing nerve endings.

5. Less wound contraction, favoring the absence of scars.

6. Less damage to neighboring tissues (not altering the surface of implants and under the recommended parameters and protocols, not affecting the dental pulp).

7. Less use of anesthetics and less need of sutures.

8. Less use of analgesics and antibiotics.

In short, the laser allows good healing and a better postoperative phase.

The disadvantages of laser use include equipment costs, compliance with strict safety standards, such as mandatory use of lenses, and training in the management of this new technology. ${ }^{10-11}$

\section{CASE REPORT}

White, male, 13-year old patient with an exophytic soft tissue lesion on the right oral mucosa in the posterior area of the occlusion line, measuring $13 \times 11 \times 8 \mathrm{~mm}$. The lesion is of soft consistency, pale pink color, oval shape, defined edges, pedunculated base, asymptomatic and slow growing. The mother reports a history of trauma for one year, while the patient says that he played with it biting it, possibly because he has an edge-to-edge bite. The lesion was initially small, and it gradually increased in size until reaching the dimensions found at the time of intervention. Once the surgical procedure was explained to the mother, an informed consent was obtained.

\section{Surgical procedure}

After applying topical gel anesthesia (20\% benzocaine), total excision of the traumatic fibroma was performed using a diode laser (Epic X, Biolase, USA; wavelength 940nm) with the following parameters: 5W in continuous mode, with a surgical tip of $400 \mathrm{~mm}$ in contact with the tissue. The lesion was gently fixed with an Adson clamp to avoid collapsing the blood supply and thus decreasing the amount of hemoglobin present, since this, like melanin, are the chromophores where the diode laser acts.

The tip was in permanent contact with the tissue, making oscillating movements until progressively causing ablation of the insertion peduncle and thus its total excision, taking $1 \mathrm{~mm}$ of tissue beyond the edges of the lesion to compare with neighboring tissue. There was no bleeding at the surgical time (Figures 1-4).

The sample was immediately deposited in a container with $10 \%$ formalin solution and sent for histopathological study; the results of this study confirmed the presumptive diagnosis of traumatic fibroma.

Throughout the surgery, patient, companion and dental staff wore the protective glasses indicated to prevent eye damage by this type of wavelength.

The patient's companion was instructed to provide analgesics: $500 \mathrm{mg}$ acetaminophen tablets were recommended every 6 hours, only if the patient had pain. Postoperative evaluations were performed at 2, 8, 15 days and at 4 months, showing excellent healing and no signs of recurrence (Figure 5). 


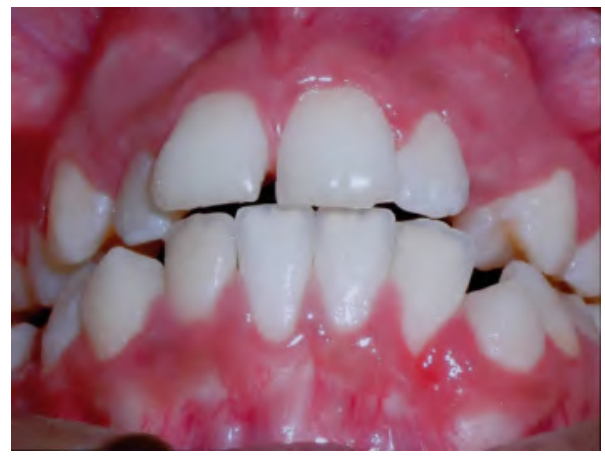

Figure 1. Initial front view, showing lesion on the right-side cheek

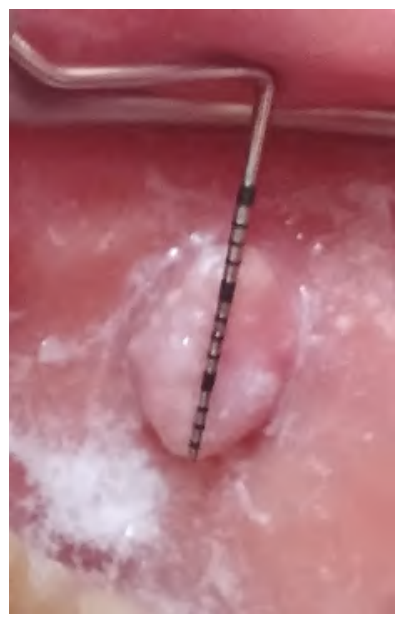

Figure 2. Measuring the fibroma

Figure 3. Firm grasping of the fibroma, avoiding a decrease in blood flow. Topical anesthesia before starting surgery
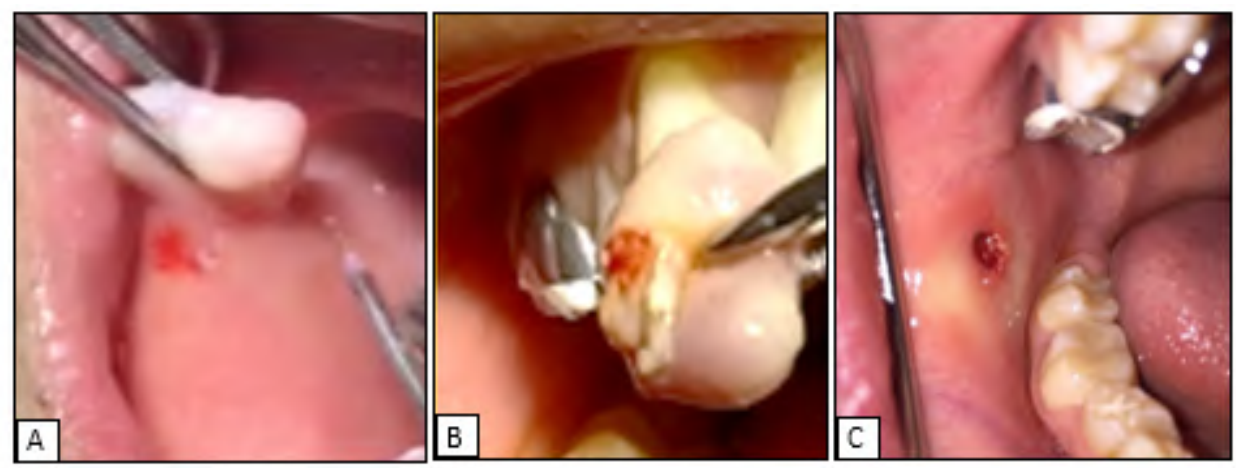

Figure 4. A. Ablation starts B. The fibroma is removed C. Surgical area immediately after removal of the insertion fibroma. No bleeding

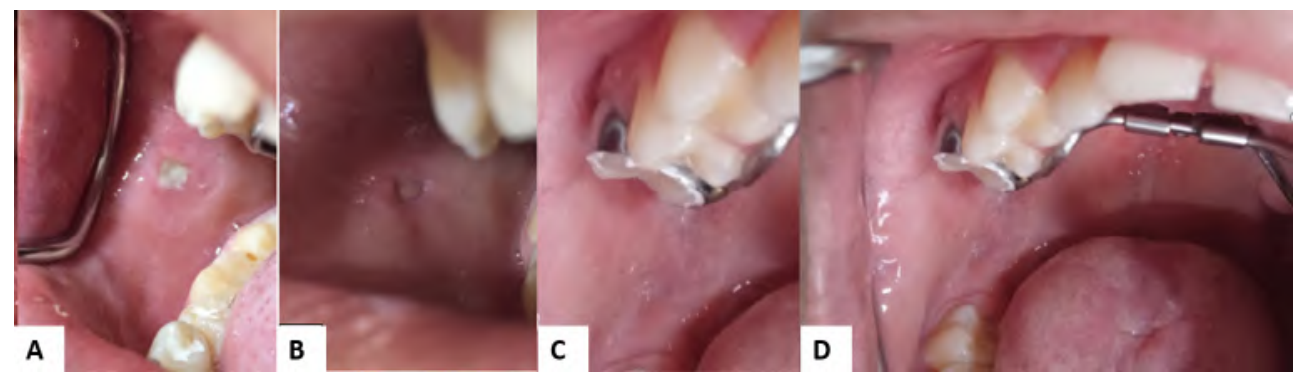

Figure 5. A. Control at 2 days B. Control at 8 days C. Control at 15 days. D. Control at 4 months 


\section{Histopathological study}

The pathological report was as follows:

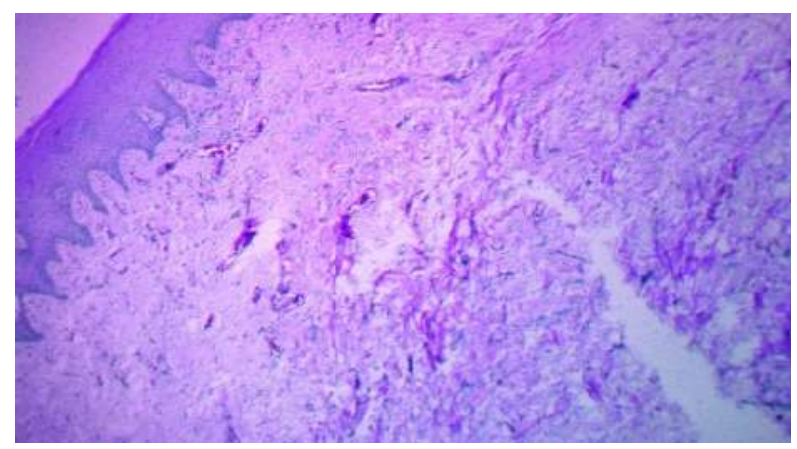

Figure 6. 10X microphotograph

Figure 6 shows an oral mucosa coated by stratified epithelium and a reactive connective tissue with collagen-dense fibers.

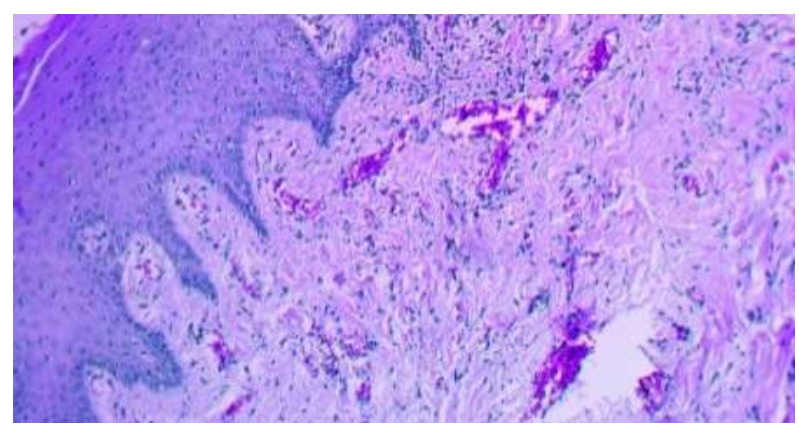

Figure 7. 20X microphotograph

Figure 7 shows the hyperplastic characteristic of the connective tissue, with small foci of lymphocytes as well as dilated and congestive blood vessels.

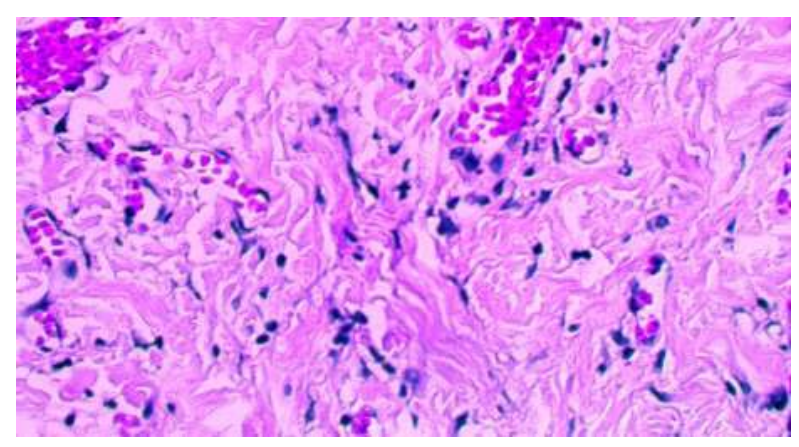

Figure 8. 40X microphotograph
Figure 8 shows in more detail the hyperplastic expression of the connective fibrous tissue forming tissue swirling. There is no evidence of malignant changes.

Procedure performed: excisional biopsy

Location: right cheek

Diagnosis: fibroma

\section{DISCUSSION}

This article described a TF in the posterior area of the right-cheek mucosa parallel to the occlusion line, in a male patient in the second decade of life.

Although most literature reports describe TFs as being more frequent in adults, they can also occur in individuals of any age and sex. ${ }^{6}$ Some authors claim that they are more predominant in females. ${ }^{5,7,12}$ There are few references on the types and incidences of oral lesions in pediatric populations..$^{5,8,22}$ Regularly, case reports are made individually as in this article.

The treatment of choice for TF, as for all reactive hyperplasia, is total surgical excision and elimination of the cause. ${ }^{8}$ Numerous treatment types have been used for excision depending on clinical and anatomical considerations. These include the use of conventional scalpel, electrosurgery, ablation with different types of infrared lasers, ${ }^{13}$ and even cryosurgery, a method that uses liquid nitrogen and is very useful in cases of patients with high surgical risk, of advanced age, with coagulation problems and pacemaker carriers. However, this technique limits the histopathology study of small samples, ${ }^{14}$ which is critical to determine the definitive diagnosis of this pathology because, although clinical history plays a key role to 
establish the initial diagnosis, as the history of a chronic traumatic or infectious etiology can be identified guiding the diagnosis towards a reactive hyperplasia, these causes may not be present, thus suggesting the presence of an actual tumor. ${ }^{13}$ The clinical capacity to recognize benign lesions of the oral mucosa by visual inspection is relatively poor ${ }^{15}$ therefore, biopsy remains an essential, mandatory tool for the diagnosis of all masses in the oral mucosa. ${ }^{13}$

Another technique reported in the literature for the removal of small fibromas is strangulation, a simple, rapid method that does not cause bleeding and does not require suture; it is not indicated in smaller, easily accessible fibromas. ${ }^{16}$

In addition, electrosurgery has been used in dentistry for soft tissue procedures since 1928. Its main advantage is the coagulant effect, which provides a non-bleeding area, increasing visibility in the surgical area. As it produces thermal energy to perform the incision, heat can be dissipated by diffusion in adjacent tissues (conduction) or in circulating blood (convection), risking a thermal lesion to neighboring tissues, which can delay healing or present an increased risk of wound dehiscence. ${ }^{17}$ Other disadvantages of electrosurgery in general and compared with laser include: the need to always use anesthetics, the unpleasant unavoidable smell, less sense of touch, cannot be used around osseointegrated implants, can cause bone damage (lower thermal control capacity, unlike laser, changing the parameters of the equipment), it is dangerous in an explosive environment, it is contraindicated in patients with pacemakers, the postoperative period is deficient in patients who have undergone irradiation or have systemic diseases such as diabetes or blood dyscrasias, ${ }^{18}$ since it does not have the biomodulatory effect that laser does have, which favors wound healing through increased fibroblast proliferation and collagen formation, as well as promoting additional release of growth factors and pain relief, as another characteristic of laser energy is its specificity in absorption and action on target cells. ${ }^{19-20}$

The comparison of the diode laser with electrosurgery has shown that the postoperative period is much better in the first 24 hours, with statistically significant pain reduction in favor of laser. ${ }^{21}$

The use of lasers in dentistry has increased in recent years, since the first presentation of the ruby laser by Maiman in 1960. Since then, various types of lasers for medical, dental and industrial use have been created. The first to be used in soft tissues in dentistry was $\mathrm{CO}_{2}$, followed by Neodymium Yag. Diode lasers were introduced in dentistry in 1999. Their energy is absorbed especially by hemoglobin and melanin (chromophores), so they are excellent for use in soft tissue surgeries, favoring coagulation, achieving rapid ablation and thus faster healing with better postoperative period. Erbium lasers have been used successfully in soft and hard tissue surgeries. ${ }^{22}$

The safety and efficacy of diode laser systems is widely proven in treatments of vascular lesions, fibromas, gingival hyperplasia, and epulis. Dental lasers offer clinical advantages, such as less bleeding, less need for anesthetics, and due to the sealing of blood and lymphatic vessels, they reduce postoperative pain and inflammation. In addition, due to their bactericidal effects, the possibility of infection is scarce when compared with conventional surgery, ${ }^{23}$ they produce less contraction of the scar tissue and maintain the elastic properties of tissues. ${ }^{24-25}$ 
The diode laser has become very popular in dentistry due to its small size and ease of use for soft tissues in small surgeries. It is also important to compare it with erbium and $\mathrm{CO}_{2}$ lasers for a lower cost. ${ }^{13}$

In this case report, the patient was anesthetized with topical gel anesthesia only, in agreement with the literature reports, where this type of topical anesthesia has been sufficient for surgical removal, ${ }^{26-27}$ thus favoring children's healthcare, since studies have shown that children are more collaborative during restorative and surgical procedures with laser. ${ }^{28}$

Lasers have proven to be the best option for the treatment of large oral fibrotic lesions, with a bleeding-free surgical area and with no postoperative complications. ${ }^{11}$ The disadvantages of lasers for the removal of soft tissue include: the cost of laser is significantly higher than that of conventional surgery; due to the potential danger of laser light, using laser requires a longer learning curve and strict precautions; laser can cause eye damage, so protective glasses are required while using it; a characteristic "burnt mucosa" odor is experienced during the procedure.

\section{CONCLUSIONS}

In this case report, results were obtained in accordance with the findings of the literature, both during surgery and in the postoperative period. Only topical anesthesia was used and there was no bleeding, which allowed an excellent view of the surgical area and operative control. The patient did not refer any pain or scar; no recurrence has occurred even after a year and a half of follow up. The acceptance, collaboration and satisfaction of the patient and his relatives are outstanding.

Following the protocols of the diode laser use can yield excellent results because it is a relatively simple and very safe method.

\section{CONFLICT OF INTEREST}

The authors declare that they have no conflict of interest.

\section{CORRESPONDING AUTHOR}

Francia Elena Triana Escobar

Escuela de Odontolog a Universidad del Valle franciaelenatriana@hotmail.com Cali, Colombia

\section{REFERENCES}

1. Neville BW, Damm DD, Bouquot JE, Allen C. Oral and maxillofacial pathology. $4^{\text {th }}$ ed. St. Louis: Elsevier; 2009.

2. Toida M, Murakami T, Kato K, Kusunoki Y, Yasuda S, Fujitsuka H et al. Irritation fibroma of the oral mucosa: a clinicopathological study of 129 lesions in 124 cases. Oral Med Pathol. 2001; 6: 91-4.

3. P rez-Salcedo L, Bascones-Mart nez A. Tumores benignos de la mucosa oral. Av. Odontoestomatol. 2010; 26(1): 11-8.

4. Santana Santos T, Martins-Filho PS, Piva MR, de Souza Andrade ES. Focal fibrous hyperplasia: a review of 193 cases. J Oral Maxillofac Pathol. 2014; 18(Suppl 1): S86-9. DOI: https://dx.doi.org/10.4103\%2F0973029X.141328 
5. Casian Romero A, Trejo Quiroz P, De Le n Torres C, Carmona Ruiz D. Hiperplasia fibrosa inflamatoria: reporte de un caso. Periodoncia Implantol Rehabiltac Oral. 2011; 4(2): 74-9. DOI: http://dx.doi. org/10.4067/S0719-01072011000200007

6. Esmeili T; Lozada-Nur F; Epstein J. Common benign oral soft tissue masses. Dent Clin North Am. 2005; 49(1): 223-40. DOI: https://doi.org/10.1016/j.cden.2004.07.001

7. Halim DS, Pohchi A, Pang EE. The prevalence of fibroma in oral mucosa among patient attending USM dental clinic year 2006-2010. Indonesian J Dent Res. 2010; 1(1): 61-6.

8. Rossmann JA. Reactive lesions of the gingiva: diagnosis and treatment options. The Open Pathology Journal. 2011; 5: 23-32.

9. Bornstein MM, Winzap-K lin C, Cochran DL, Buser D. The CO2 laser for excisional biopsies of oral lesions: a case series study. Int J Periodontics Restorative Dent. 2005; 25(3): 221-9.

10. Rossmann JA, Cobb CM. Lasers in periodontal therapy. Periodontology 2000. 1995; 9: 150-64.

11. Shalawe WS, Ibrahim ZA, Sulaiman AD. Clinical comparison between diode laser and scalpel incisions in oral soft tissue biopsy. Al-Rafidain Dent J. 2012; 12(2): 337-43.

12. Torres-Domingo S, Bagan JV, Jim nez Y, Poveda R, Murillo J, D az JM et al. Benign tumors of the oral mucosa: a study of 300 patients. Med Oral Patol Oral Cir Bucal. 2008; 13(3): E161-6.

13. Ortega-Concepci n D, Cano-Dur n JA, Pe a-Cardelles JF, Paredes-Rodr guez VM, Gonz lez-Serrano J, $\mathrm{L}$ pez-Quilles J. The application of diode laser in the treatment of oral soft tissues lesions: a literature review. J Clin Exp Dent. 2017; 9(7): e925-28. DOI: https://dx.doi.org/10.4317\%2Fjced.53795

14. L pez-Labady J, Villarroel M, Lazarde J, Rivera H. Fibroma traum tico: revisi $\mathrm{n}$ de la literatura y reporte de dos casos. Acta Odontol Venez. 2000; 38(1): 47-9.

15. Allon I, Kaplan I, Gal G, Chaushu G, Allon DM. The clinical characteristics of benign oral mucosal tumors. Med Oral Patol Oral Cir Bucal. 2014; 19(5): e438-43. DOI: https://doi.org/10.4317/medoral.19387

16. Correa PE, Arias S. Resecci $n$ de fibroma en mucosa oral: $t$ cnica del estrangulamiento. Rev. CES Odont. 2016; 29(1): 82-7.

17. Silverman EB, Read RW, Boyle CR, Cooper R, Miller WW, McLaughlin RM. Histologic comparison of canine skin biopsies collected using monopolar electrosurgery, CO2 laser, radiowave radiosurgery, skin biopsy punch, and scalpel. Vet Surg. 2007; 36(1): 50-6. DOI: https://doi.org/10.1111/j.1532-950X.2007.00234.x

18. Funde S, Baburaj MD, Pimpale SK. Comparison between laser, electrocautery and scalpel in the treatment of drug-induced gingival overgrowth: a case report. IJSS Case Rep Rev. 2015; 1(10): 27-30. DOI: https:// doi.org/10.17354/cr/2015/43

19. Pang P, Andreana S, Aoki A, Coluzzi D, Obeidi A, Olivi G et al. Laser energy in oral soft tissue applications: position paper. J Laser Dent. 2010; 18(3): 123-31.

20. Carroll J, Milward M, Cooper PR, Hadis M, Palin WM. Developments in low level light therapy (LLLT) for dentistry. Dent Mater. 2014; 30(5): 465-75. DOI: https://doi.org/10.1016/j.dental.2014.02.006

21. Chandna S, Kedige SD. Evaluation of pain on use of electrosurgery and diode lasers in the management of gingival hyperpigmentation: a comparative study. J Indian Soc Periodontol. 2015; 19(1): 49-55. DOI: https://doi.org/10.4103/0972-124X.145823

22. Patel H, Fernandes $\mathrm{S}$, Ranadheer E. Excision of irritation fibroma in a child with diode laser: a case report. J Dent Lasers. 2014; 8: 34-8. DOI: https://doi.org/10.4103/0976-2868.134124 
23. Desiate A, Cantone S, Profeta G, Grassi F R, Ballini A, Tullo D. 980nm diode lasers in oral facial practice: current state of the science and art. Int J Med Sci. 2009; 6(6): 358-64. DOI: https://doi.org/10.7150/ ijms.6.358

24. Yag e-Garc a J, Espa a-Tost AJ, Berini-Ayt s L, Gay-Escoda C. Treatment of oral mucocele-scalpel versus C02 laser. Med Oral Patol Oral Cir Bucal. 2009; 14(9): e469-74.

25. Strauss RA, Jones G, Wojtkowski DE. A comparison of postoperative pain parameters between CO2 laser and scalpel biopsies. J Oral Laser Appl. 2006; 6(1): 39-42.

26. Kafas P, Angouridakis N, Dabarakis N, Jerjes W. Diode laser lingual frenectomy may be performed without local anesthesia. Int J Orofac Sci. 2008; 1: 1.

27. Kafas $\mathrm{P}$, Stavrianos $\mathrm{C}$, Jerjes $\mathrm{W}$, Upile $\mathrm{T}$, Vourvachis $\mathrm{M}$, Theodoridis $\mathrm{M}$ et al. Upper-lip laser frenectomy without infiltrated anesthesia in a paediatric patient: a case report. Cases J. 2009; 2: 7138. DOI: https:// doi.org/10.1186/1757-1626-2-7138

28. Kafas $\mathrm{P}$, Dabarakis $\mathrm{N}$, Theodoridis $\mathrm{M}$. Performing gingivoplasty without injected anaesthesia: a case report. Surg J. 2008; 3(2): 27-9.

29. nc E. Comparison of gingivectomy procedures for patient satisfaction: conventional and diode laser surgery. Seljuk Dent J. 2017; 4(1): 6-9. DOI: https://doi.org/10.15311/1441.309572

30. Amid R, Kadkhodazadeh M, Talebi MR, Hemmatzadeh S, Refoua S, Iranparvar P et al. Using diode laser for soft tissue incision of oral cavity. J Lasers Med Sci. 2012; 3(1): 36-43. 